\title{
The Fight Against Illegal Booty (Catch) Fish
}

\author{
Vasily Yarovenko \\ Oksana Poleshchuk
}

Doctor of law, Professor, Law school, Far Eastern Federal University, The Honored of law the Russian Federation Vladivostok, Russia; E-mail: yarovenko.vv@dvfu.ru

\section{Doi:10.5901/mjss.2015.v6n6p319}

\section{Abstract}

\begin{abstract}
The authors analyze the State of combating illegal production (catch) fish from the standpoint of the criminal law and judicial practices of different regions of the Russian Federation. Attention is paid to the subject of the criminal act, which differentiated into three categories. The value of for qualifications illegal production (catch) fish has information on the location of the offence, which shall be proved by establishing the place of the actual fish catch and its comparison with the actual data contained in the documents and other evidence to substantiate his special status. The establishment of the crime scene by $h .2$ art. 256 of the CRIMINAL CODE shall be exercised in accordance with the rules of international law governing use of the open sea, it is part of the maritime space, outside the jurisdiction of any State and is in use by all States, and restrictions within the exclusion zones. The article drew attention to the establishment of the time of the offence. So, for favourable fish spawning time frame when all fishing is prohibited, or the time when it is forbidden to produce fish of certain species and in particular locations. Therefore, in proving the Commission of prohibited production time requires references to documents in the case file, containing information on time (year, month, day). The peculiarity of this type of crime is How to hide, so action and results (masking under Relax on water, fishing gear permitted, mushroom, etc.). Poachers posing for tourists, mushroom pickers have camp away from the reservoir and gear cloaked under a variety of household items. The authors show that another problem of illegal booty (catch) fish is to obtain information about the subject of the offence. In practice, at the initial stage of the disclosure of crime the environment itself shows signs of poaching, but data about the person (persons), which has committed a crime, no.
\end{abstract}

Keywords: extraction fish, poaching, investigating crimes, subject, time, place, method, concealment, damage

\section{Introduction}

Illegal extraction (catch) the fish turned into a huge business with their plants, Gates abroad by corrupt relationships. Formed criminal groups were formed with good equipment, armament and distribution roles. For example, in Kalmykia created entire floating city of boats and rafts that are overgrown with reeds floodplains. There hunters bring everything you need. For the surrounding area being monitored of these floating cities dissolve within half an hour (Budberg, 2002).

Despite geographical distance, climate, ethnic composition and differences, all the poachers are engaged in illegal fishing during the prohibition of fishing in the spawning period. Caught fish and harvested caviar stored in special places along the shoreline of Lake Baikal, and the lower Volga River in Khabarovsk and Primorsky region, Sakhalin region. Thus, the situation showed signs of poaching, but data about the person (persons), which has committed a crime, no.

In Russia prescribes liability for illegal extraction, as well as the acquisition or sale of knowingly obtained through criminal means fish. It is difficult to implement a set of measures for the prevention of crime in the process of transportation and storage of illegally caught fish. In fact, when a vehicle is detected in fish products without documents, it shall be verified and further criminal action against unknown persons who exercised fish.

\section{Methodology}

The study was conducted from 2012-2015 years. The authors analyzed the theoretical and empirical studies that have been done by other authors in previous years. Research methodology is based on the analysis of regulations, doctrinal and practical elements. In the process of preparing the article applied scientific (General logical, comparison, analysis, synthesis of abstraction, generalization) research and Private method (formal dogmatic, etc.). Selected research methods allow us to better address the problems of combating illegal extraction of fish. Considerable emphasis is placed on the use of the method of interpretation of law and comparative law method. 
Objective: to consider the problems of combating illegal exploitation of fish with the position of the current legislation and the recommendations of scientists, as well as to make suggestions for their solution.

\section{Discussion}

Detection and investigation of crimes in the sphere of production (catch), processing of aquatic biological resources depends on the state and poznavatel'skoj activities that primarily use information for suppressing and preventing poaching and related crimes.

Criminal conduct in Art 256 of the CRIMINAL CODE of the RUSSIAN FEDERATION described using the concept of "the illicit extraction (catching). The term "swag" decrypted using the lookup word "(catch)", which comes from the verb perfect kind of "catch". Catch - this notion, meaning getting the actual recovery, in contrast to the word "fishing" meaning not the result, but the process of the realization of the intentions of "catch" (Il'ina, 2014). Unlike the Russian Federation act in Article 281 of the Criminal Code of Belarus described the concept of "extraction".

The Federal law «On fisheries and the conservation of aquatic biological resources "from December 20, 2004 in red the Act of July 2, 2013 No. 148-FZ» defines the term "production (catch)" as "removal of aquatic biological resources of their habitat" (p. 8, art. 1), that is, to associate it with the actual receipt of the result.

The concept of extraction in the literature as the process unfolds the catch, slaughter, removal and other exceptions to the natural environment of aquatic animals and plants, ending de facto possession subject production, regardless of the amount of extracted (Zhalinsky, 2006; Parshina, 2003). Similar views expressed by N.A. Lopashenko (Lopashenko, 2002).

Criminal responsibility begins when setting information that extraction was carried out illegally (Lebedev, 2009; Knayzev, Churakaev, Chuchaev, 2009). Extraction is illegal if carried out in violation of environmental laws governing and fish production bases, sea animals, other aquatic animals or fishing of marine plants (Lopashenko, 2002).

The Plenum of the No. 26 «On the application by the courts of legislation on the criminal liability in the field of fisheries and the conservation of aquatic biological resources (article 253, 256 of the Criminal Code)» said: "Illegal production (catch) of aquatic biological resources (article 256 of the Criminal Code) the courts should understand the actions aimed at the removal of Habitat and (or) possession in violation of environmental laws (for example, without obtained permission in accordance with the law, in violation of the provisions of this permission in prohibited areas, in respect of certain types of prohibited to extraction (catching) of aquatic biological resources in the forbidden time using prohibited fishing gear), provided that such acts are committed by a person using self-propelled transport floating means, explosives or chemicals, electric shocks or other means of mass extermination of aquatic animals and plants, spawning or migration paths to him, on specially protected natural territories, in the disaster area or in the area of environmental emergency, or when such activities have caused massive damage. The courts in each case it is necessary to establish and reflect in the sentence what exactly described illegal mining (catch) or a way to catch aquatic biological resources, together with an indication of the provisions of the Federal law and other normative legal acts, regulating the implementation of fisheries that have been infringed "(p. 3); in prohibited areas, in respect of certain types of prohibited to extraction (catching) of aquatic biological resources in a prohibited time, using banned fishing gear).

L.V. Mikhailova highlights two main ways of illegal exploitation of aquatic biological resources: a) the illicit exploitation of biological resources under the guise of legal activities fisheries complexes. It catches living aquatic resources that are not specified in the authorization; catch more than indicated in the authorization; unauthorized fishing pond, square area; fishing in the forbidden time; extraction of prohibited and not specified in the authorization tool fishing etc are unrecorded excess by shelter from the accounting part of the catch are fraudulent acts, underestimated the amount and quality of sea products in the admission-transfer, in prohibited areas, in respect of certain types of prohibited to extraction (catching) of aquatic biological resources in a prohibited time, using banned fishing gear).

L.V. Mikhailova highlights two main ways of illegal exploitation of aquatic biological resources: a) the illicit exploitation of biological resources under the guise of legal activities fisheries complexes. It catches living aquatic resources that are not specified in the authorization; catch more than indicated in the authorization; unauthorized fishing pond, square area; fishing in the forbidden time; extraction of prohibited and not specified in the authorization tool fishing etc are unrecorded excess by shelter from the accounting part of the catch are fraudulent acts, underestimated the amount and quality of sea products in the admission-transfer, number of ascents of guns fishing, tucked from the regulatory bodies by falsifying data in marine fishing magazines;

b) bio-extraction by organized criminal groups. These groups are characterized by a clear distribution of roles: some solve organizational issues, others are involved in fishing and seafood, their primary processing and reprocessing, and the third involved in the transport and sale of products (Mikhailova, 2014). 
To combat illegal booty (catch) aquatic biological resources, you must set the time of the end. Prey of aquatic biological resources should be considered as a completed offence since their actual extract from that environment, rather than from the date of the action directly aimed at the removal of aquatic biological resources of the environment.

When qualifying under article 256 of the CRIMINAL CODE in indictments in $87.5 \%$ of the cases the subject of crimes cited variously as "fish salmon species, sometimes with the addition of the adjective" precious "or a specific species of Salmon (Pink salmon, Keta, Siberian salmon, Red salmon, Silver salmon, Chinook salmon, Sema). Thus in $45.5 \%$ of them were listed species illegally caught fish for salmon (Il'ina, 2014).

The subject of the offence under article 256 of the criminal code, are aquatic biological resources that are not related to high-value species listed in the Red data book of the Russian Federation and (or) protected the international treaties of the Russian Federation. When the delimitation of articles 256 and $258^{1}$ The CRIMINAL CODE of the RUSSIAN FEDERATION on the subject of crime, it is recommended that you be guided by the RF Government Decree of 31.10 .2013 No. 978 "On approval of the list of most valuable wildlife and aquatic biological resources belonging to the species listed in the Red data book of the Russian Federation and (or) protected the international treaties of the Russian Federation, for the purposes of articles $226^{1}$ and $258^{1}$ of the Criminal Code of the Russian Federation".

When the illegal exploitation of the subject matter of criminal assault is conditionally divided in to 3 categories. The first category includes valuable species (species) of fish, crustaceans, shellfish, marine mammals, sea plants, echinoderms. This category should include other types of fish catches which is prohibited by the rules of the amateur and the sporting fisheries fish age fishing size applications.

The second category includes any list of fish living in waters where fishing is banned at this time (reserve, spawning fish, fish hatchery, environmental emergency zones).

The third category includes fish, total weight (quantity) which exceeds the standards set by the rules of the fishery (Rochkov, 2006).

For qualifying illegal production (catch) fish has value information on the place of the Act. In part 1 of art 256 of the CRIMINAL CODE of the RUSSIAN FEDERATION water biological resources and environment of their dwelling specially protected through the provision of such traits as committing the offence in the ground or on the spawning migration paths to them ( $\mathrm{p}$. «v»), on specially protected natural territories or in the disaster area or in the area of environmental emergency ( $p$. «g».).

Spawning sites, designated as the scene of the crime, means place of Russian sturgeon fish and Azerbaijan, and migration paths-passage routes. Among scientists there are proposals for clarification of the list of such places. So, U.S. Goncharova considers firstly, spawning is not the place and time, and time is clearly defined, and not always those places filled with fish. Secondly, because spawn has an important breeding ground for all kinds of fish, fishing in the spawning site, but not at the time did not cause significant damage to the State, unlike the time of spawning (Goncharova, 2007).

Article 256 of the CRIMINAL CODE does not indicate the breeding sites of other fish species, as well as space for the rearing of aquatic and marine mammals. Because it is a space of the criminal-legal regulation, it is proposed to expand the paragraph "b" due to indications of breeding, foraging and rearing primarily aquatic biological resources belonging to special categories and protected environmental rules and regulations in accordance with the special regimes established by legal acts.

Scene of the crime shall be proved by establishing the place of the actual fish catch and its comparison with the actual data contained in the documents and other evidence to substantiate his special status. For example, the testimony of expert, when reservoir is not considered or temporarily has no commercial value or is not fully understood. The specialist can determine what was caught fish spawning during its catch or not, whether the fish catch on the migration path (Larichev, etc., 2007).

Evidence confirming the place of illegal mining, are appropriately certified copies of documents about the decision of the authorities of the designation of a specific territory in which is located the pond or reservoir, place the reserved territory, damaging, determine what specific place in the pond or body of water are the migration paths or fish spawning grounds. Significance there is and documents for reservoir, plot reservoir, a zone of ecological disaster or emergency environmental situations.

The establishment of the crime place by h. 2 art. 256 of the CRIMINAL CODE shall be exercised in accordance with the rules of international law, governing use of the open sea it is part of the maritime space, outside the jurisdiction of any State and is in use by all States, and restrictions within the exclusion zones (Kalinichenko, 2009). N.A. Lopashenko properly emphasizes: "prohibition on the extraction of marine mammals in them due to the fact that reproduction occurs in these places animals, cultivation of them juveniles, or those places used as a familiar mammal rookeries, leisure, etc."(Lopashenko, 2002).

An important factor is to establish the time of the offence. So, for fish spawning create time limit when all fishing is 
prohibited, or the time when it is forbidden to produce fish of certain species and in particular locations. Therefore, in proving the Commission of prohibited production time requires references to documents in the case file, containing information on time (year, month, day)(Krepecheva, 2013).

For example, when spawning should prove short duration of action for immediate extraction, an offence mainly at night because during the day time the pond or its station where spawning occurs, protected or there has been a fishery officers.

In some cases, the exact time of the commission of the offence is established by searching for witnesses, with the necessary information. Probative value has a time of day at which the offence was committed with the definition of opportunities to observe directly the criminal actions. However, the onset of dusk, dark, like most typical to commit illegal actions during spawning, can this interfere.

If the time is set as accurately as possible, it is difficult to prove that he was perpetrating a particular person. The timing of the commission of the crime sometimes depends on how the fish production. Time can be in multiple categories: a) time limits the catch of fish (fish spawning period). Set in relation to this specific type of reservoir, fish stocks, in accordance with the rules of the fishery; b) time during which is committed illegal fish catch (one-time episode or during a certain period of time); in the immediate time of the offence) (morning, afternoon, evening, night).

The peculiarity of this type of crime is How to hide, so action and results (masking under Relax on water, fishing gear permitted, mushroom, etc.). Poachers posing for tourists, mushroom pickers have camp away from the reservoir and gear cloaked under a variety of household items. In addition, criminals can use hazard warning systems, involving and radios and audio alerts, and much more, with the appearance of a fisheries inspector.

Hiding specific action can be achieved:

a) disguise, installed gear (reeds, algae) and floating means of transport (the lack of registration of on-board rooms), hiding traces of fishing on the beach, the location of the camp (Mill) at a distance from a water body;

b) acts in reduced visibility (fog, darkness);

c) the installation of observation posts, using radio, light and sound signals, using special hazard warning signal (appearance of a fisheries inspector);

d) using the household disguised onion household harvestersth gear (electro fishing masquerades as radio, burg- under the telescopic fishing rod) (Rozhkov, 2006).

Another problem of illegal booty (catch) fish is to obtain information about the subject of the offence. In practice, at the initial stage of the disclosure of crime the environment itself shows signs of poaching: detected by poachers, set in gear pond fishing gear of valuable breeds of fish illegally caught fish, personal belongings of poachers that reside in the pond or on the shore, but data about the person (persons), which has committed a crime, no. This situation is more complicated for the initial phase of the investigation, so as to obtain information about a person is possible only by simultaneous production of operatively-search actions and investigations. In particular, it is necessary to place the detection gear installed by poachers, organize the ambush with the purpose of their detention. This situation is more complicated for the initial phase of the investigation, so as to obtain information about a person is possible only by simultaneous production of operatively-search actions and investigations. In particular, it is necessary to place the detection gear installed by poachers, organize the ambush with the purpose of their detention.

Ambush can last a long time, caught fish may die. If the same tackle select and release caught fish, the law enforcement agencies will be deprived of evidence that will help prosecute poachers. The problem faced by the employees of the guard and the police quite often and is resolved in favor of fish-gear removed and the fish are released. In practice, most often the scene is not performed, traces of vehicles used in the illegal exploitation of fish, traces in the fishing camp nobody fixes. Tracking and evidentiary information remains widely (Krepecheva, 2013).

With the position of the current legislation of the tracking work is valid only for serious and particularly serious criminal cases. Formulations of articles 256 and $258^{1}$ of the CRIMINAL CODE of the RUSSIAN FEDERATION such skills, unfortunately, is not. Therefore, there are substantial grounds for amending the criminal procedure legislation of a number of changes, which would have combined the pre-qualification stage, inquiry and investigation.

From 10 June to 15 September in the Sakhalin area forces the Sakhalin police, in collaboration with State bodies involved in the protection and reproduction of aquatic biological resources, complex operational and preventive measures "Putin-2014".

When you implement special operations ("Putin", "The poacher", etc.) are detained persons during transportation, storage or sale of fish or products (for example, calves), if there is information that fishing or extraction of such fish is currently prohibited. However, there is no information on the direct identification of persons in illegal fishing and related traces.

During the period of operation in the area of illicit traffic of aquatic biological resources identified 512 crimes, 458 of 
which are offences under article 256 of the CRIMINAL CODE of the Russian Federation (poaching). So, 9 September, employees of the Department of the Russian Interior Ministry in conjunction with the FSB officers Ohe of Russia on the Sakhalin area revealed a large underground plant for processing illegally bagged aquatic biological resources, where they seized more than 9 tons of Kaluga. The amount of damage was around 8 million roubles.

It was instituted by articles 256 and $258^{1}$ CRIMINAL CODE 501. The greatest number of criminal cases initiated in the Poronajskom area -82, followed by Korsakov - 74, Dolinsk - 61, Aniva - 58.

Among poachers distinguish three categories of persons in the course of their activities. The first group includes people by occupation is not related to fisheries, but are close to him. This includes residents of the cities, villages, towns, whose territory bordering water bodies. The second group includes people related by virtue of working with water objects and, hence, with stocks of fish. This category includes fishermen engaged in industrial fish prey. They allow the following offences and crimes: catch fish, not specified in the licence, fishing on the pond or unstated squared, fishing in a prohibited time or prohibited instruments etc. Third group includes persons engaged in systematic predatory fish illicit mining. They are combined into a criminal organized group with clear internal organization, a powerful lobby in power structures and so on. In these groups there is a strict division of lab our. The lowest step organization occupy fishermen who almost all year round, except for storms, engaged in direct fishing (Varetsa, 2006).

The analysis suggests that illegal fish production typical criminal professionalism, i.e. the kind of criminal classes, who:

1) is the source of livelihood for the subject (the person receives from the illegal extraction of some income);

2) requires specific knowledge and skills to achieve the ultimate goal (for example, a person may operate a motorized vehicle floating tool, able to navigate the sea, can use certain tools and techniques for the illegal extraction of fish, etc.);

3) makes certain contacts with hostile environment (for example, there is a need for channels of distribution of fish caught by illegal means, etc.);

4) defines a sustainable kind of criminal activities (mainly homogenous commit crimes), in this case under art 256 of the criminal code.

Another problem of illegal booty (catch) fish is to obtain information about the amount of major damage, which is necessary to address the question of instituting criminal proceedings. For qualifying illegal production (catch) on the items on the "b", "v" and "g" h. 1 article 256 of the CRIMINAL CODE the onset of major damage is not required. This raises the question, what is the minimum damage to the solution of the question of instituting criminal proceedings. The absence of its regulation is often an important argument when challenging the legality of criminal proceedings.

\section{Conclusion}

The illegality of the production (catch) of aquatic biological resources is determined by its wrongfulness, which specified indicating her enjoyment of the place, time and methods of production (catch).

The fight against the illegal spoils her fish should include information about subject criminal assault, ways to commit and conceal crimes, places, time and the subject. Listed circumstances give the opportunity to present the nature of the training commit and conceal crimes. They provide not only prevention of crimes, but completeness, efficiency of investigating crimes related to the illegal exploitation of fish, as well as practices from implementing penalties.

\section{References}

Budberg, A. Putin was taken by helicopter to the floating. Moscow. Journal Green world. 2002, № 17-18, p. 7.

Goncharova, U.S. Illegal mining of aquatic animals and plants: criminal law, comparative and criminological research. Katege. cand. DICs. legal. sciences. Saratov, 2007. http://lawtheses.com/nezakonnaya-dobycha-vodnyh-zhivotnyh-i-rasteniy-ugolovnopravovoe-komparativnoe-i-kriminologicheskoe-issledovaniya

Zhalinsky, A.E. Educational and practical commentary on the Criminal Code of the Russian Federation. 2-ed. Moscow: Eksmo, 2006, p.793.

Il'ina, E.P. Nezakonnay extraction (catching) of aquatic biological resources (Kamchutskogo region): DIS of candidate of legal sciences. Moscow. 2014, p. C. 98.

Knayzev, A.E., Churakaev, D.B., Chuchaev, A.I. Environmental crimes. Scientific-practical guide with article by article material to chapter 26 of the Criminal Code of the Russian Federation. Moscow: Prospect, 2009, p. 71.

Kalinichenko, M.M. The legal regime of territorial protection of the marine environment. Moscow: Publishing House "Gorodets". 2009.

Krepecheva, S.K. Diagnostic evaluation of situational characteristics of illicit production and transport of aquatic biological resources as a means of proof in criminal cases//Proceedings of the Tula State University. Economic and legal sciences. Tula, No. 4-2. 2013, p. 
260-267.

Larichev, V.D., etc. Identification of crimes related to the illegal exploitation of aquatic animals and plants (CCRF, art. 256). Moscow, 2007, p. 42-43.

Lebedev, V.M. Special part of the Criminal Code of the Russian Federation: comment, litigation, statistics. Moscow: Publishing House "Gorodets", 2009, p. C. 721.

Lopashenko, N.A. Environmental crimes. The commentary to chapter 26 of the CRIMINAL CODE of the Russian Federation. SPb: Publisher: Publisher R. Aslanov "Legal Center Press, 2002, p. 181.

Mikhailova, L.V. Basic types and ways of committing crimes at the sites of sea transport (based on OVD Far Eastern Federal District).Journal of Juridical Science and law enforcement. No. 1 (27), 2014, p. 113-114.

Parshina, I. A. Illegal fishing: Penal and criminological aspects. DIS. of candidate of legal sciences. Krasnodar, 2003.

Rochkov, I.I. Identification and disclosure of crimes in sphere of aquatic bioresources. Volgograd: VA Ministry of Internal Affairs of Russia, 2006, p. 17.

Varetsa, V.P. Criminological analysis of specificity of personal characteristics the offender engaged in illegal fishing. Theory and practice of community development. Journal. No. 3 vol. 6. 2006, p. 117. 